\title{
Financial markets and the current account: emerging Europe versus emerging Asia
}

\author{
Sabine Herrmann · Adalbert Winkler
}

Published online: 10 September 2009

(C) Kiel Institute 2009

\begin{abstract}
Financial globalisation has been associated with divergent current account patterns in emerging markets. In this paper we test for the relevance of financial market characteristics in explaining different current account patterns in emerging Europe and emerging Asia. We find that better developed and more integrated financial markets increase emerging markets' ability to borrow abroad. The degree of financial integration within the convergence clubs as well as the extent of reserve accumulation are found to be the most significant factors to explain divergent current account patterns in emerging Europe and emerging Asia.
\end{abstract}

JEL Classification $\mathrm{F} 15 \cdot \mathrm{F} 21 \cdot \mathrm{O} 16 \cdot \mathrm{O} 52 \cdot \mathrm{O} 53$

Keywords Real convergence - Economic integration - Saving and investment . Current account developments · Financial markets · Emerging market economies

\section{Introduction}

Over the last decade, the process of financial globalisation has been associated with strongly divergent current account patterns in emerging market economies engaged in a rapid catching-up process. While countries in emerging Europe and emerging Asia have been receiving substantial gross financial inflows, both regions have differed significantly with regard to direction and size of net capital flows. Most countries in emerging Europe, in line with standard economic

S. Herrmann $(\bowtie) \cdot$ A. Winkler

Deutsche Bundesbank, Wilhelm-Epstein Strasse 14,

60431 Frankfurt, Germany

e-mail: sabine.herrmann@bundesbank.de 
theory, ${ }^{1}$ have been reporting substantial current account deficits over the last 10 years (Bussière et al. 2004). Growth has been driven by domestic demand, in particular by investment, partly financed by foreign savings. By contrast, in emerging Asia - as described by the so-called Lucas paradox (Lucas 1990) - the convergence process has been associated with current account surpluses, while periods of expansionary domestic demand and deteriorating net exports proved to be indicators of an ensuing crisis (Felipe and Lim 2005).

There is a broad consensus in the literature that the state of financial development and international financial integration plays a key role in explaining why emerging economies' current account patterns contradict standard theory (Prasad et al. 2007) or are in line with predictions based on consumption-smoothing behaviour (Blanchard and Giavazzi 2002; Abiad et al. 2007). Against this background, this paper analyses the relationship between financial markets and current account developments in emerging market economies in Europe ${ }^{2}$ and Asia. ${ }^{3}$ It aims at shedding light on the question to what extent financial market characteristics have been at the heart of the strikingly different current account patterns observed in both regions.

The paper goes beyond the literature in several respects: first, we test for the significance of a range of variables indicating different types and dimensions of financial development and integration. Second, we analyse the relationship between financial markets and current account developments by way of comparison between emerging Europe and emerging Asia. Third, we make recourse to the concept of convergence clubs, with two peripheries and their two cores. The United States is identified as the core in the case of emerging Asia, while the euro area/EU-15 is the core of the convergence club in Europe. ${ }^{4}$ This does not only reflect differences in the overall pattern of convergence but also allows us to distinguish between global and intra-regional financial integration within the convergence clubs. Fourth, we go beyond the identification of statistically significant determinants and reveal to what extent these variables actually contribute to the level of the current account balances.

Our analysis suggests that financial markets and financial integration are important factors in determining current account balances and their dispersion. At the same time, the overall state of financial development and integration provides little mileage for explaining the divergent current account patterns in emerging Europe and emerging Asia. Rather, the differences reflect the different ways financial

\footnotetext{
${ }^{1}$ Standard economic theory suggests that the process of income convergence will be accompanied by capital flows from rich to emerging economies, reflecting return differentials and economic agentś preferences for consumption smoothing, see Obstfeld and Rogoff (1996). .

2 The emerging European countries are the new European Union (EU) Member States Bulgaria, the Czech Republic, Estonia, Hungary, Latvia, Lithuania, Poland, Romania, Slovakia and Slovenia as well as the candidate (Croatia, FYR Macedonia and Turkey) and potential candidate countries (Albania, Bosnia and Herzegovina, Montenegro and Serbia) for EU accession.

3 The emerging Asia group refers to developing Asian countries such as China, Indonesia, Malaysia, the Philippines and Thailand, as well as the newly industrialized Asian economies, i.e. Hong Kong, Korea, Singapore and Taiwan. Furthermore, India and Vietnam are part of the sample.

${ }^{4}$ However, we do not attempt to explain global configurations of current accounts or "global imbalances", even though we are well aware that the condition of a global current account balanced by definition implies that current account balances across countries must be interrelated.
} 
integration with the respective core has been proceeding. Moreover, the different ways of financial integration are strongly rooted in a different overall integration approach between core and periphery taken in the two convergence clubs.

The paper is structured as follows: Sect. 2 introduces the convergence club concept, while Sect. 3 provides an overview of real convergence and current account developments in emerging Europe as well as in emerging Asia. Section 4 reviews the literature on the role of financial markets for the current account. In Sect. 5, we test direction and significance of several financial sector variables for current account positions in the European and Asian emerging market economies. Section 6 summarises and concludes.

\section{The concept of convergence clubs}

Standard economic theory predicts that countries with a relatively low per capita income should catch up with richer ones, driven by differences in the marginal returns to capital. On a global level, however, the empirical evidence suggests increasing divergence of income levels over time (Pritchett 1997). This contradiction between theory and evidence triggered among others the convergence club concept (Abramovitz 1986). It takes a historical perspective by noting two features of modern growth processes: (a) there have been leading countries in terms of growth and development; (b) there has been only a small group of countries who managed to converge with the leader over time. Leader and followers form convergence clubs with a core (leader) and a periphery (converging countries). Convergence is driven by spillovers from the core to the periphery as converging economies engage in similar lines of production and in extensive trade or financial linkages with the core (Baumol 1986).

We apply the convergence club concept to emerging Europe and emerging Asia, as-following Eichengreen (2004) - the process of globalisation can still be very much analysed in a core-periphery framework, with the industrial countries acting as the core and emerging markets acting as the periphery. However, several indicators suggest that the two emerging regions converge to two different cores.

In Europe the convergence process of emerging economies has been shaped to a large extent by the process of accession to the European Union (EU). This is most obvious with regard to institutional integration, ${ }^{5}$ but applies to economic integration, i.e. trade and investment links between the euro area and emerging Europe, as well. Moreover, when taking a monetary perspective, the countries in emerging Europe predominantly use the euro as their anchor currency. Against this background we identify a European convergence club with the euro area as the core and emerging Europe as the periphery. By contrast, the convergence process in emerging Asia lacks a comparable institutional framework linking the periphery to the core. However, several indicators in trade and investment point to the United States as the core country emerging Asian economies aim at converging to. The

\footnotetext{
${ }_{5}$ All countries in emerging Europe have either become Member States of the EU or are candidate and potential candidate countries with the perspective of becoming an integral part of the EU.
} 
same applies to the degree of financial integration as the stock of consolidated foreign bank claims by US banks is most pronounced in most Asian countries under review. ${ }^{6}$ In addition, the US dollar serves as the main anchor Asian economies base their exchange rate policies on. Thus, we identify a second convergence club with the United States as the core and emerging Asia as the periphery.

The convergence club concept and the identification of two different convergence clubs with emerging European and emerging Asian countries constituting the respective peripheries broadens the analysis of financial development and financial integration in both regions by adding an additional, regional dimension. Current account patterns in both peripheries may not only be influenced by the progress in domestic financial development and integration in global financial markets, but also by the depth and form of financial integration between core and periphery within the respective convergence club.

\section{Real convergence and current account developments in central, eastern and south-eastern Europe and in emerging Asia-an overview}

Between 1994 and 2006, emerging Europe and emerging Asia have seen similar dynamics of catching up. On average, Asian countries experienced a slightly higher growth rate $(5.6 \%)$ than the emerging European countries $(4.1 \%){ }^{7}$ By contrast, in emerging Europe, gross domestic product (GDP) per capita, compared to the euro area average, rose by more than $12 \%$ points in the period under review, while Asian countries-on average-improved their relative per capita income position ${ }^{8}$ vis-àvis the United States by only $6 \%$ points. The convergence process was strongly influenced by the 1997/1998 financial crisis. Thailand, Indonesia, the Philippines and Malaysia, i.e. four of the five countries that were hit hardest, rank last in terms of catching up with US per capita income between 1994 and 2006.

In Europe, the convergence process has been accompanied by substantial current account deficits (Fig. 1). ${ }^{9}$ Between 1994 and 2006, only seven countries recorded 1 or 2 years with current account surpluses, either in the mid-1990s or as part of an adjustment process after a period of financial turbulences. By contrast, Asian countries show, on average, a positive current account position in most of the years under consideration (Fig. 2). The 1997 financial crisis marks a clear turning point, as five countries, Indonesia, Malaysia, Thailand, Hong Kong and Korea, saw a shift from deficits to sustained surpluses. China, Singapore and Taiwan recorded current account surpluses over the whole review period, while developments in the remaining countries have been more heterogeneous.

\footnotetext{
6 In China, Hong Kong, Indonesia and Thailand Japanese banks hold the largest claims.

7 For Bosnia and Herzegovina, the average applies to the period 1999-2006 to avoid a bias due to the immediate post-war recovery with exceptionally strong annual growth rates. Data for Serbia are available only from 1999. Montenegro is not included in the analysis.

${ }^{8}$ If not explicitly mentioned differently, GDP per capita figures are in purchasing power parity (PPP) terms.

${ }^{9}$ In general, smaller countries recorded higher current account deficits, explaining the wedge between the weighted and non-weighted average of current account deficits in Figs. 1 and 2.
} 


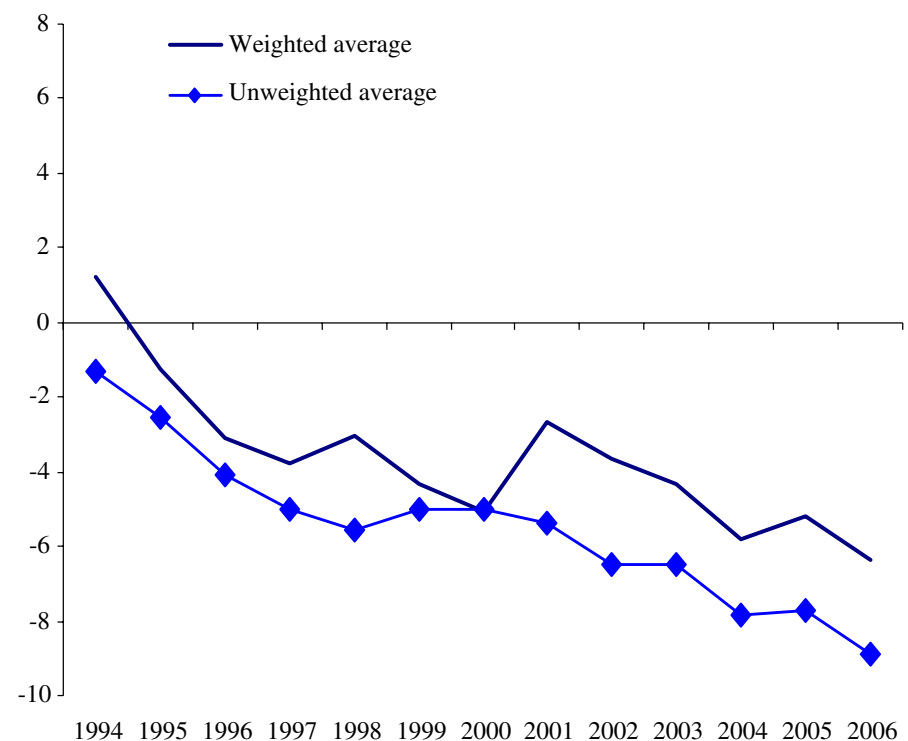

Source: IMF, authors calculations.

Fig. 1 Current account balances in emerging Europe, 1994-2006 (weighted/non-weighted averages, as $\%$ of GDP)

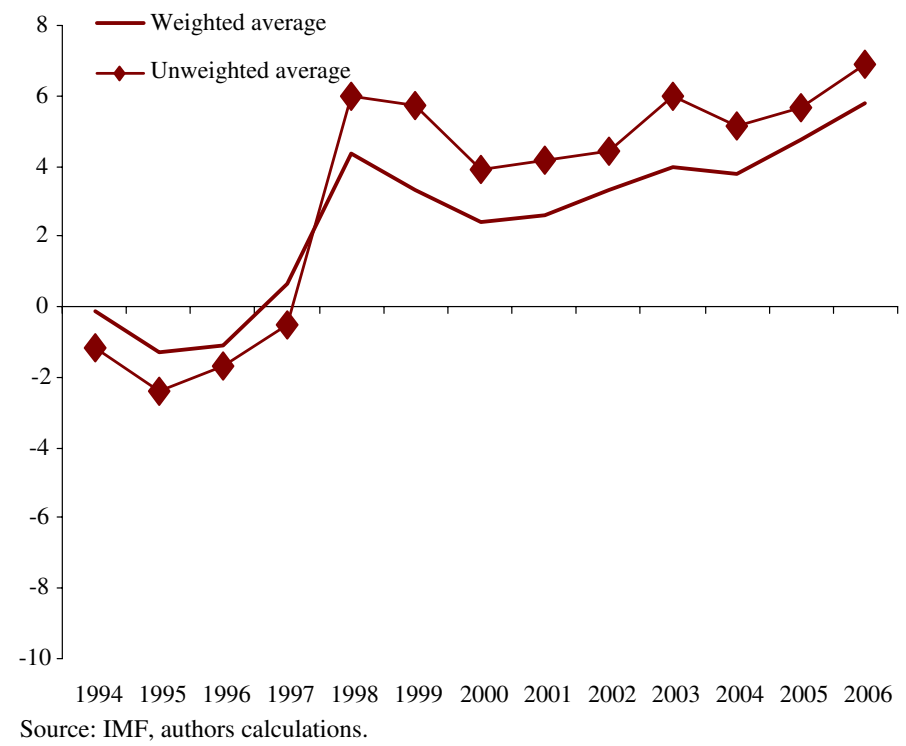

Fig. 2 Current account balances in emerging Asia, 1994-2006 (weighted/non-weighted averages, as \% of GDP)

In emerging Europe, current account deficits have been mainly reflecting a rise in investment, while in emerging Asia, current account surpluses after the financial crisis can almost completely be attributed to a decline in investment (investment 
drought). The strong rise in the weighted savings rate in Asia is to a large extent driven by developments in China, where public sector saving has been continuously increasing over time (public savings glut).

In the following, we analyse whether the characteristics of the financial markets might have an important bearing on the development of the current account and to what extent they can explain divergent external balances in emerging Europe and Asia.

\section{The current account and financial development-a review of the literature}

In recent years, a broad consensus emerged in the literature that underdeveloped and weak financial markets represent one factor explaining why most emerging markets have not recorded substantial current account deficits as predicted by standard theory. Underdeveloped and weak domestic financial markets hamper the ability of emerging markets to transform domestic savings into domestic investment and to engage in substantial foreign borrowing. Thus, emerging markets with underdeveloped financial markets will-in principle_-invest less than predicted by standard theory and hence will show a tendency towards current account surpluses. ${ }^{10}$

Financial development is difficult to quantify. In the literature a low degree of financial development has been associated with

- a low level of financial intermediation and financial sector quality,

- a strong accumulation of foreign exchange reserves, serving as a signalling and shock-absorbing device substituting for highly developed financial markets, and

- a limited ability to engage in international financial integration.

Concretely, three approaches linking underdeveloped financial markets with current account developments in emerging markets can be distinguished.

1. Financial intermediation and financial sector quality. Underdeveloped financial sectors are seen as an impediment for emerging economies to convert domestic savings and capital inflows into high-quality assets and thus investment, creating a shortage of assets (Caballero 2006). As a result, financial capital flows uphill, i.e. from emerging to mature markets where funds can be invested in a stronger institutional setting offering higher returns. ${ }^{11}$ This might lead to current account surpluses in emerging economies despite their low capital-labour ratios. As financial development would induce a rise in domestic investment, a higher degree of financial intermediation and financial sector quality should be associated with a current account deterioration (Mendoza et al. 2006).

\footnotetext{
10 Theoretically, however, the impact on the current account is ambiguous, as financial sector development may foster domestic savings as well as domestic investment. Edwards (1995), Chinn and Ito (2005) and Hermann and Jochem (2005) suggest that an efficient financial sector is associated with an increase in domestic savings which would lead to an improvement of the current account.

11 This idea is similar to the approach of Ju and Wei $(2006,2007)$ which assumes that countries with a low quality of financial institutions will participate in international financial integration by recording FDI inflows while at the same time realising outflows of other financial capital. Thus, underdeveloped financial sectors are by-passed by economic agents through integrating with mature market economies.
} 
2. Build-up of foreign exchange reserves. The precautionary savings view (Aizenman and Lee 2005; Aizenman 2007) identifies foreign exchange reserve accumulation by emerging market economies as a substitute for developed financial markets in absorbing terms of trade shocks. Episodes of financial crisis reveal financial sector weaknesses in emerging economies and reinforce the need to build-up foreign reserves. The new mercantilist view (Dooley et al. 2003, 2007) claims that financial markets in emerging economies are unable to integrate in the global financial system due to a lack of credibility. To gain credibility, emerging markets have to accumulate foreign assets, mainly foreign exchange reserves.

3. Financial integration. Underdeveloped financial sectors are regarded as a major obstacle for financial integration which hampers borrowing abroad and thus weakens the link between income convergence and the current account. Vice versa, a high degree of financial integration, as for example in Europe (Blanchard and Giavazzi 2002; Abiad et al. 2007) allows catching-up economies to run sizeable current account deficits. ${ }^{12}$

The literature suggests that a lack of financial development is a key obstacle for emerging markets to engage in consumption-smoothing activities, thereby affecting the current account. In the following, we test the various propositions associated with the different dimensions of financial sector development empirically for the two regions under review.

\section{The current account and financial development-an empirical investigation}

\subsection{Model specification}

We test direction and significance of financial development for the current account in the emerging regions under review by estimating an inter-temporal model which defines the current account balance as the difference between domestic saving and investment. Saving as well as investment ratios are replaced by a function of different variables. ${ }^{13}$ The estimated equation follows a reduced-form approach similar to those used by Chinn and Prasad (2000), Chinn and Ito (2005, 2007) and Abiad et al. (2007):

$$
\left(\frac{\mathrm{CA}}{\mathrm{GDP}}\right)_{i t}=\alpha_{i}+\alpha_{x} X_{i t}+\varepsilon_{i t}
$$

The dependent variable is the current account balance in per cent of GDP. The vector of explanatory variables $X_{i t}$ includes basic macroeconomic determinants of saving and investment, namely the per capita INCOME (in PPP terms) relative to

\footnotetext{
12 However, financial integration may also support behaviour in line with the Lucas paradox, if financial integration is a precondition for the ability of emerging market economies to invest in mature financial markets (Greenspan 2003). Thus, from a theoretical point of view, the impact of deeper financial integration on the current account is, again, found to be ambiguous.

13 Usually, saving and investment as well as their main determinants are to some extent correlated. Thus, some of the selected variables might affect both, the saving and the investment rate as well.
} 
the reference country as well as its squared term (INCOME_SQUARED) ${ }^{14}$ and the DEPENDENCY ratio (ratio of the non-working to the working population). ${ }^{15} \mathrm{We}$ expect that the relationship between the relative per capita income and the current account to be positive and a higher dependency ratio to be associated with a higher current account deficit. In addition, we test for the significance of the overall level of gross CAPITAL inflows (as a percentage of GDP) and the impact of flows taking the form of foreign direct investment (as a percentage of GDP), FDIGDP. Both variables ${ }^{16}$ are expected to carry a negative sign, as FDI inflows have been found to boost domestic investment more strongly than other capital flows (Bosworth and Collins 1999; Mody and Murshid 2002).

The focus of our empirical investigation is on testing for the impact of financial development on the current account by including several financial variables representing different dimensions of financial development.

The ratio of private CREDIT to GDP, M2 in relation to GDP and a banking CRISIS indicator according to Caprio and Klingebiel (2003) ${ }^{17}$ are variables directly capturing quantity and quality of financial intermediation in emerging Asia and emerging Europe. A higher degree of financial intermediation and a better quality of the domestic financial sector (less crisis-prone) should be associated with higher current account deficits (lower surpluses), as the financial sector is assumed to take a more active and facilitating role in fostering domestic investment.

The stock of foreign RESERVES in per cent of GDP is used as a proxy for the build-up of precautionary savings/collateral, indicating substantial financial sector weaknesses. Thus, we expect the variable to have a positive coefficient. As the reserve accumulation is also seen as a policy tool to deal with terms of trade shocks impinging on the real effective exchange rate or to pursue an export-led growth strategy, we also test for the impact of the real effective EXCHANGE rate (log), with real appreciation leading to a worsening of the current account.

We also control for the influence of financial integration, expecting a negative coefficient, as a higher degree of integration facilitates borrowing abroad and thus strengthens the ability of countries to perform consumption-smoothing activities.

\footnotetext{
14 The euro area serves as a reference for the relative per capita income in the European economies and the US per capita income is the benchmark for the Asian emerging markets. Following Chinn and Prasad (2000), the squared term is included to allow for possible non-linearities in the relationship between relative per capita income and current account positions in line with the so-called stage of development hypothesis (Debelle and Faruqee 1996). The theory suggests that at an early stage of the convergence process, a country's external financing requirement may initially rise with increasing per capita income before it starts declining with higher levels of development.

${ }^{15}$ In addition, we tested for the significance of other macroeconomic variables, following for example Chinn and Ito $(2005,2007)$, including the government budget balance, the net external position, a trade openness indicator (ratio of exports and imports to GDP) as well as the terms of trade. However, they turned out to be insignificant and, thus, were excluded from the analysis.

${ }^{16}$ We take lagged values of the FDI variable as we are interested in the long-term production effects on investment which might go beyond the one-time effects in the context of the financial transaction.

17 The variable is important to take account of the impact of the Asian financial crisis in 1997/1998. Following Gruber and Kamin (2005), we only take account of systemic financial crisis. The dummy variable is one when the country suffers a crisis and zero otherwise.
} 
Expanding the analysis by Abiad et al. (2007) and Blanchard and Giavazzi (2002), we test for the relevance of four aspects of financial integration:

- the regulatory state of financial openness as measured by the CHINN_ITO index,

- the OVERALL INTEGRATION in the international financial system, with the sum of foreign assets and liabilities/GDP serving as a proxy (Lane and MilesiFerretti 2006),

- the degree of INTRA-convergence club financial INTEGRATION, proxied by the consolidated foreign bank claims of the US/euro area BIS reporting banks on the respective periphery countries in emerging Asia and emerging Europe (expressed as a percentage of GDP of the recipient country), and

- the share of FOREIGN-owned BANKING assets (in per cent of total banking sector assets in the periphery countries), measuring the degree of financial integration with regard to financial institutions. Given that most of the foreign banks entering emerging European countries have been banks from the euro area, we interpret this variable as an additional indicator for financial integration within the respective convergence clubs.

We also expect that financial integration affects the current account differently in different stages of economic development. Thus, all variables measuring the degree of financial integration are interacted with the per capita income variable.

Finally, $\varepsilon_{i t}$ represents the disturbance term of the estimation. The database covers 27 emerging markets in Europe and Asia, namely the 16 SEE/CEE countries as well as 11 developing and newly industrialized Asian economies. ${ }^{18}$ Due to the transition in emerging Europe, the period of analysis is restricted to $1994-2006 .{ }^{19}$ Thus, we take annual data, as the short observation period does not allow testing with a panel that contains non-overlapping 5-year period averages of the data for each country, as done in Chinn and Prasad (2000), Gruber and Kamin (2005) and Abiad et al. (2007). ${ }^{20}$

Our approach raises the issue of endogeneity. ${ }^{21}$ Capital flows may be largely endogenous, i.e. a consequence of current account developments, rather than an exogenous variable. For example, a high degree of financial integration might reflect strong demand for financing in the countries under review rather than exogenously determining savings and investment, and thus current account developments in the respective country. There is no unanimous answer to this question in the literature

\footnotetext{
${ }_{18}$ For a detailed description of the countries under review and the estimated variables see the Data Appendix.

19 Data were available from 1994 to 2006, except for CHINN_ITO (1994-2005), DEPENDENCY (1994-2004), INTRA INTEGRATION (1994-2005) and OVERALL INTEGRATION (1994-2004). Thus, the time period for the FGLS estimation in Table 1 is 1994-2004.

${ }^{20}$ Chinn and Prasad (2000) examined the robustness of the medium-term results at an annual frequency. They found that while, in general, estimates at an annual frequency are less precise, most coefficients have the same sign and often similar magnitudes.

21 In addition, it might be argued that a substantial part of the equation is based on a simple balance of payment identity, as several of the explanatory variables are linked to the financial account. However, among these variables only the FDIGDP variable, lagged by 1 year, properly accounts for a financial account sub-balance. As a result, there is no risk of estimating a balance of payment identity.
} 
(see, e.g. Fry et al. 1995). However, as it is assumed that credit markets in emerging economies are constraint by supply factors due to underdeveloped financial sectors and inefficient financial institutions (contrasting with more mature financial markets, where credit can be assumed to be mainly demand driven), it is consistent to treat variables depicting characteristics of financial markets and financial integration as exogenous determinants of domestic saving and investment decisions. Furthermore, the variables used in the estimation can be treated as exogenous, as-with the exception of FDIGDP - they do not have a net flow dimension, but depict either stock variables or gross flows. Finally, we take account of a possible endogeneity in a technical sense by referring to an instrumental variable (IV) estimator (see Sect. 5.3).

\subsection{Estimation results}

Two models are estimated using a static feasible generalized least squares (FGLS) estimation with fixed effects, autoregressive (AR) terms and panel-corrected standard errors taking into account a heteroskedastic error structure as well as a correlation between countries: (1) a basic model capturing the impact of the macroeconomic variables as well as the overall level of capital flows and FDI, respectively and (2) a financial development model that takes into account the various variables of financial development and integration introduced in Sect. 5.1. ${ }^{22}$ The FGLS estimation results are presented in Table 1.

The results of the basic model stress the importance of the domestic macroeconomic variables and confirm the expected coefficients. The estimation results show a negative coefficient for the income variable and a positive coefficient for its squared term, indicating that there is a U-shaped relationship between relative income and the current account balance. This supports the stage of developmenthypothesis arguing that in the initial stage of the convergence process the perceived investment opportunities in low-income countries will rise, which are reflected in larger current account deficits as per capital income levels are increasing. Only at a more advanced level of development, the relationship between relative per capita income and the current account balance turns positive, as predicted by the consumption-smoothing hypothesis. Moreover, as in Chinn and Prasad (2000),

\footnotetext{
22 The panel unit root tests of Levin et al. (2002), Breitung (2000), Im et al. (2003) as well as an augmented Dickey-Fuller (ADF) test based on Maddala and Wu (1999) were applied. These tests confirmed that the left-hand side variable and most other variables were stationary. Exceptions include the variables CREDIT and CHINN_ITO, which were found to be non-stationary and were differentiated. As the income convergence process and the concept of convergence clubs we apply to the countries under review should result in a stationary relative income variable, we include per capita income in levels (INCOME and INCOME_SQUARED) in spite of the mixed empirical evidence of the panel unit-root tests. This procedure is in line with the most recent literature. Moreover, a time trend is included in the FGLS estimations in order to control for the trend-stationary variables (M2GDP, CRISIS, OVERALL INTEGRATION). The results are robust with respect to different models and different specifications; see Sect. 5.3 for a robustness check. AR terms and trends are not reported in the table. The coefficients in Table 1 depict the marginal impact of the independent variables on the current account as fixed effects are included in the estimation. Thus, Table 1 shows the general effects of the explanatory variables which are common in all countries. The regression was estimated with Eviews 6.
} 
Table 1 Determinants of the current account-Results of the FGLS estimations

\begin{tabular}{lcc}
\hline & $(1)$ Basic model & (2) Financial development model \\
\hline INCOME & $-0.672(-4.63)^{* * *}$ & $-1.124(-5.64)^{* * *}$ \\
INCOME_SQUARED & $0.005(3.13)^{* * *}$ & $0.006(3.07)^{* * *}$ \\
DEPENDENCY & $-36.403(-4.83)^{* * *}$ & $-24.977(-1.26)$ \\
CAPITAL & $-0.128(-3.99)^{* * *}$ & $-0.117(-5.03)^{* * *}$ \\
FDIGDP $(-1)$ & $-0.177(-3.34)^{* * *}$ & $-0.357(-6.05)^{* * *}$ \\
RESERVES & & $0.275(9.67)^{* * *}$ \\
EXCHANGE & & $0.923(0.75)$ \\
D(CREDIT) & & $-6.938(-3.69)^{* * *}$ \\
M2GDP & & $-0.009(-0.54)$ \\
CRISIS $(-1)$ & & $1.094(2.34)^{* *}$ \\
D(CHINN_ITO) & & $-0.016(-0.08)$ \\
OVERALL INTEGRATION & & $-0.023(-7.34)^{* * *}$ \\
INTRA INTEGRATION & & $-0.170(-3.33)^{* * *}$ \\
FOREIGN BANKING & & $-0.159(-4.33)^{* * *}$ \\
Interaction term: & & $0.0003(3.58)^{* * *}$ \\
overall integration $\times$ income & & \\
Interaction term: & & $0.0028(2.35)^{* *}$ \\
intra integration $\times$ income & 0.000 & \\
Interaction term: & 351 & $0.0023(3.31)^{* * *}$ \\
foreign banking $\times$ income & & \\
$R^{2}$ adj. & 0.9 & 0.9 \\
Durbin-Watson & & 2.0 \\
$F$-Statistic & & 0.000 \\
No. of observations & & 351 \\
\hline
\end{tabular}

***, ** Denote significance at the level of 1 and $5 \%$, respectively; $t$-values in ***, **, * the level of 1,5 and $10 \%$, respectively; $t$-values in parentheses

countries with a higher dependency ratio show a higher current account deficit. ${ }^{23}$ Furthermore, larger gross inflows of capital as well as stronger FDI inflows, both expressed as a percentage of GDP of the recipient country, increase the current account deficit significantly indicating that foreign capital acts as a major source of funding investment. In doing so, the impact of FDI on the current account seems to be remarkably stronger than the influence of capital inflows in general.

The financial development model confirms that developed financial markets allow emerging economies to invest more due to a more sophisticated financial intermediation. This is confirmed by significant negative coefficients of real credit growth $^{24}$ and positive coefficients for the CRISIS and RESERVES variables. The experience of a banking crisis seems to lead to an withdrawal of foreign capital,

\footnotetext{
${ }^{23}$ However, the variable fluctuates in the different model specifications with respect to size of the coefficient as well as with respect to significance.

24 As the variable has been differentiated, it represents the change in the private credit to GDP ratio. The negative coefficient of the M2 ratio points in the same direction, but is not significant.
} 
which works towards a current account surplus and a higher stock of foreign exchange reserves is significantly linked with an improvement in the current account balance. By contrast, we find that an appreciation of the real effective exchange rate is not significant in the model specification presented in Table 1.

The model confirms that all indicators of financial integration are negatively correlated with the external balance, with only the Chinn-Ito index failing to be significant. Thus, the model lends support to the hypothesis that the degree of overall financial integration, the extent of financial integration within the convergence clubs and the penetration of foreign banks into domestic banking sectors matter for developments in the current account balance.

Finally, all variables representing the de facto degree of financial integration interact positively and significant with the relative income level. Two major results arise:

- First, the relationship between financial integration and the current account depends on the level of income. As a result, the parameter of overall financial integration $(-0.023+0.0003 \times$ per capita income $)$, intra-regional financial integration $(-0.170+0.0028 \times$ per capita income $)$ and foreign banking asset share $(-0.159+0.0023 \times$ per capita income $)$ is negative for low-income countries and positive for high-income countries. Thus, in line with the findings of Abiad et al. (2007), a higher level of financial integration leads to an increased dispersion of current account balances, as-given a certain income level-deficits and surpluses will be larger compared to a situation with a low level of financial integration.

- Second, the degree of financial integration has a positive impact on the link between the relative income position and the current account, as a higher level of financial integration contributes to a higher income coefficient $(0.0003 \times$ overall financial integration, $+0.0028 \times$ intra-regional financial integration, $+0.0023 \times$ foreign banking asset share). Thus, depending on the underlying relationship between per capita income and the current account, a higher degree of financial integration strengthens either consumption-smoothing behaviour or will be associated with a shift in the underlying relationship between relative per capita income and the current account from the Lucas paradox to consumption smoothing.

Overall, the results indicate that more developed financial systems in emerging economies and deeper financial integration are associated with a deteriorating current account balance. Thus, at the current income level of the countries under review, financial development and integration seem to enhance countries' ability to perform consumption-smoothing activities.

\subsection{Robustness check}

First, by estimating a dynamic IV estimator according to Anderson and Hsiao (1981) we controlled for possible endogeneity of certain right-hand side variables. This estimator also avoids the Nickell bias. The constant, the second lag of the endogenous variable, the exogenous variables and their lags as well as two lags of 
the pre-determined variables RESERVES, EXCHANGE, CAPITAL and FDI were used as instruments. The results are comparable with the FGLS estimation. However, the advantages of the dynamic estimator are offset by a lower efficiency compared to the static estimation, also reflecting the limited amount of observations. Moreover, the Nickell bias should not play a major role in our context, given the relatively small number of cross-sections and the relatively large number of time periods. Thus, we stick to the static estimation results.

Second, instead of using a linear time trend (in order to control for trendstationary variables) we run an estimator with period fixed effects (in addition to the cross-section fixed effects). Period time dummies are a more general specification of a time trend. The results do not deviate significantly from the FGLS estimator, however, show a slightly reduced significance.

Third, alternatively, we follow a kind of encompassing method by introducing step by step additional variables to see what changes occur when adding additional variables. The coefficients of the estimated variables in these alternative model specifications-except for the dependency ratio which shows a certain variation in different models - are robust to these alterations. Furthermore, we consider alternative measures of financial sector development and quality. While the spread between lending and deposit rates turns out to be not significant, the share of nonperforming loans to total loans is significantly negative, providing additional support for the hypothesis that more advanced financial markets are associated with higher current account deficits.

Fourth, we also controlled for the effect of the exchange rate regime. Although standard economic theory does not give any indication that-in the long run-the exchange rate regime has a bearing on the current account balance, it cannot be excluded that short-run adjustment effects occur. These might be of relevance as our analysis is based on annual data. Following IMF (International Monetary Fund) (2006a) we include a dummy variable representing the exchange rate regime. It is found that this variable has a significant positive impact on the current account, implying that fixed exchange rate regimes are associated with a deterioration of the current account balance. However, this variation does not impair the outcome of the remaining variables.

Fifth, in a different estimation we exclude China from the analysis as developments in China stands out within the Asian sample. The results deviate only marginally from the original model. Moreover, based on the idea that there might be disadvantages of forcing two different convergence clubs into the straightjacket of a common regression, we run separate estimations of the European and the Asian sample. The results are very much comparable with the original estimation. However, due to the fact that the number of observations is much smaller, some variables exhibit a less pronounced significance.

Sixth, we run an analysis of the residuals of the financial development model. Figure 3 shows the predicted and actual values of the current account as well as deviations of the actual values from the predicted values. These deviations can be attributed to additional factors or exogenous shocks which are not included in the model. The analysis suggests that the model explains a substantial fraction of the actual current account positions. Moreover, residuals are normally distributed and do not follow an AR process. 


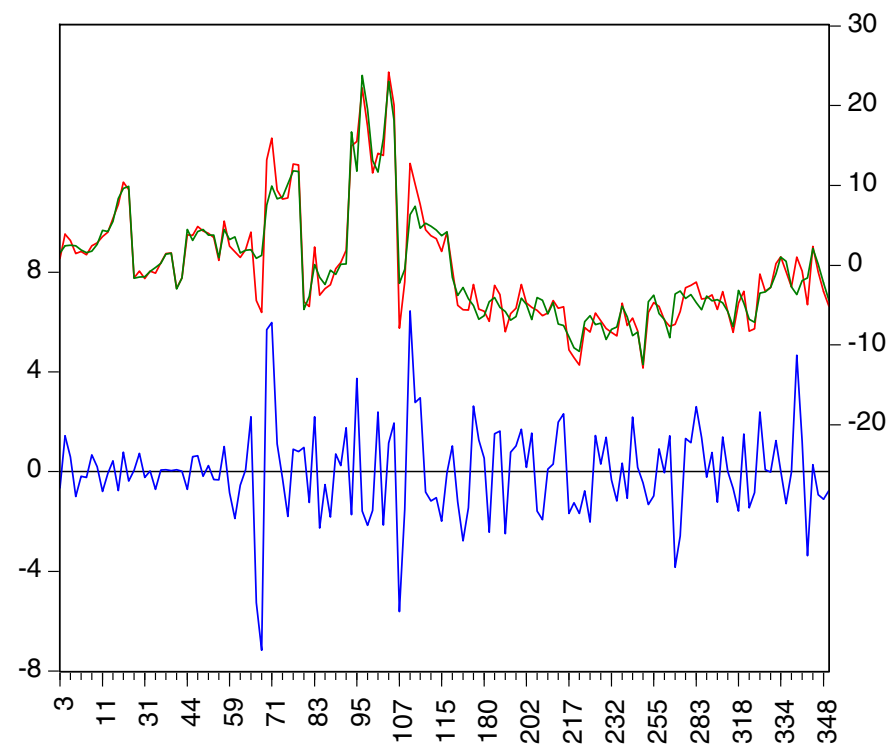

Residual (scale to the left)
Actual (scale to the right)
Fitted (scale to the right) $\quad$ in \% of GDP

Source: IMF, authors calculations.

Fig. 3 Analysis of residuals

Seventh, we replace the relative per capita income variables with the differentiated INCOME variable as the results of the unit-root tests are rather mixed. The coefficient of the differentiated INCOME variable is negative, implying that countries in emerging Europe and emerging Asia experiencing a more pronounced income growth (relative to the core country) are found to record higher current account deficits or lower surpluses. Assuming that poorer countries grow faster than richer countries, this result indirectly lends support to the consumption-smoothing hypothesis, implying that capital flows downhill from rich to poor countries. However, this change in the specification of the income variable does not significantly alter the remaining results, in particular the impact of the financial variables.

\subsection{Contribution analysis}

As a second step, we perform a contribution analysis that provides information on the economic significance of the estimated variables. In particular, the analysis reveals to what extent the individual variables have given rise to different patterns of current account developments in emerging Europe and Asia. ${ }^{25}$ The main results can be summarised as follows:

\footnotetext{
25 The data result from multiplying the estimated parameters of the financial development model by the annual figures of each factor using the average in the two regions. Thus, the analysis informs about the relative contributions of the variables to the predicted current account/GDP ratio for both peripheries.
} 
Macroeconomic factors have been important and economically relevant determinants of current account developments in emerging Europe and emerging Asia. In particular, the demographic situation seems to have a strong impact on agents' savings behaviour and thus current account balances. The ongoing strong catchingup process also induces an inflow of capital to both regions under consideration.

The Asian financial crisis had a strong positive impact on current account developments in emerging Asia. This is evidenced by the CRISIS variable as such, but is also picked up by INCOME, CAPITAL and D(CRDEDIT). While in the aftermath of the Asian crisis income and credit growth slowed in emerging Europe as well, leading to an improvement in the current account, the impact was much milder than in emerging Asia.

However, the increasing divergence of current account deficits in emerging Europe versus emerging Asia has been mainly driven by (1) the rapidly rising presence of foreign banks in emerging Europe as well as a significantly lower level of financial integration between core and periphery in the United States/emerging Asia convergence club compared to the European convergence club, and (2) the rapid accumulation of foreign exchange reserves in emerging Asia which was outpacing similar developments in emerging Europe (Fig. 4).

By contrast, standard indicators of financial intermediation [M2GDP, $\mathrm{D}(\mathrm{CREDIT})]$ and overall financial integration (OVERALL INTEGRATION, see Fig. 4) provide little mileage in explaining the divergent pattern of current account developments in the two peripheries. This mainly reflects the fact that on average these indicators do not show a significantly higher level and/or stronger trend of financial development in emerging Europe compared to emerging Asia. By contrast, the level of financial development (M2GDP) and the degree of integration in the global financial system is actually higher in emerging Asia than in emerging Europe, ${ }^{26}$ ceteris paribus suggesting that emerging Asian countries should have shown a more negative current account balance than countries in emerging Europe.

The latter result might reflect data weaknesses. Standard indicators of financial development might fail to capture borrowing constraints businesses and households effectively face (Eichengreen 2006; IMF (International Monetary Fund) 2006b), as they might not reveal the true dimension of supply constraints domestic economic agents face in acceding financial services, e.g. the ability of households to take consumer and mortgage credit. Quantitative measures of financial development also inherently miss the quality aspect, which is, however, difficult to measure. The same applies to the indicators capturing the extent of financial integration, as they may be distorted by policy actions, for example the sum of total foreign assets and liabilities also includes foreign exchange reserves, or pick up financial integration in a rather partial way, like claims by BIS reporting banks on emerging market economies.

At the same time, the results seem to suggest that the character of financial integration matters. Current account developments in emerging Europe have not

\footnotetext{
26 This is not contradictory to the evidence provided by Abiad et al. (2007), suggesting an extraordinary degree of financial integration in Europe, as it is to a large extent driven by cross-border asset holdings in the European core. Focusing on emerging Europe only, the sum of foreign assets and liabilities-on average, expressed as a percentage of GDP - is still lower than in emerging Asia.
} 
OVERALL INTEGRATION (NET)

$\begin{array}{lllllllllll}1994 & 1995 & 1996 & 1997 & 1998 & 1999 & 2000 & 2001 & 2002 & 2003 & 2004\end{array}$

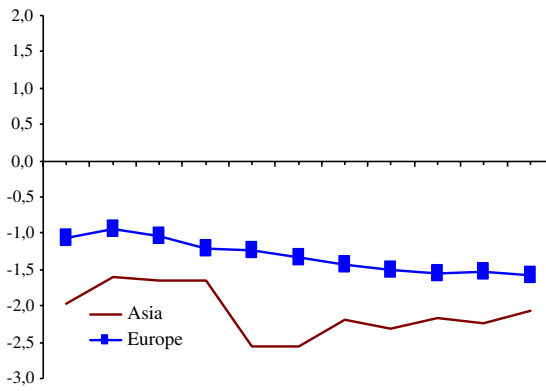

FOREIGN BANKING (NET)

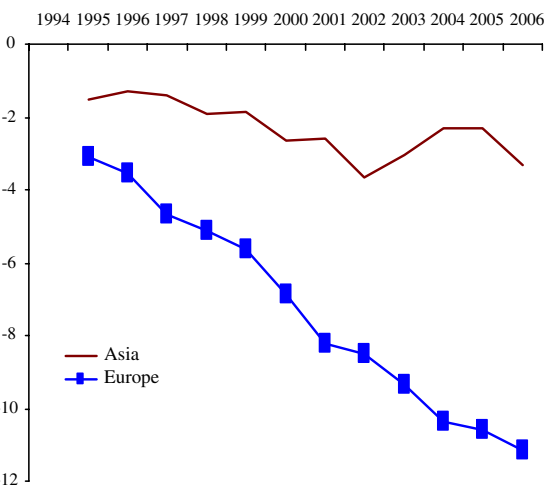

INTRA INTEGRATION (NET)

199419951996199719981999200020012002200320042005

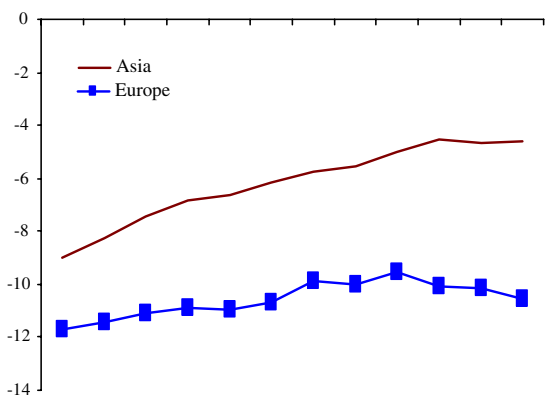

RESERVES

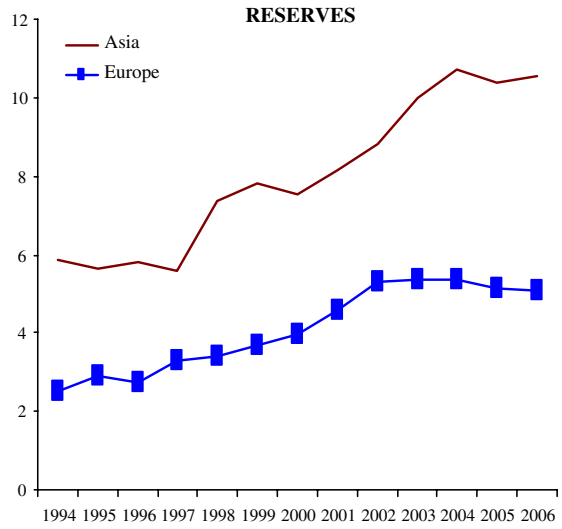

Source: IFS, authors calculations.

Fig. 4 Contribution of financial integration variables (net) and foreign exchange reserves to current account developments in emerging Europe/emerging Asia (in \% of GDP)

been different because the region has significantly better developed financial systems or because it is financially deeper integrated in the global economy than emerging Asia. Rather, emerging Europe has been different because its financial integration with the core has been very different than in emerging Asia, reflecting the fact that the European integration process has been a process of "deep integration", ${ }^{27}$ where new member states, the periphery, have been joining the core by accepting key European institutions, laws and governance practices.

This "deep" character of European integration may have facilitated financial integration within the convergence club as it mitigated or even erased-at least to a large extent - the inherent credibility gap between core and periphery, allowing emerging Europe to run substantial current account deficits and limit reserve accumulation compared to emerging Asia. It may also explain why foreign banks from the euro area/EU-15 have entered the domestic banking sectors in the region at such a scale and thus created a very special environment for financial sector quality

\footnotetext{
27 Rodrik (2007) distinguishes between "deep integration" within a nation, like the United States, and the European Union, and "shallow integration" for the remaining country universe.
} 
in emerging Europe, facilitating other investment inflows. These factors may not be captured by the standard variables of financial development and integration, and could be a reason why their economic relevance in explaining divergent current account patterns in emerging Asia and Europe has been rather marginal.

\section{Conclusions}

The paper analysed the significance and economic relevance of financial factors for divergent current account developments in emerging Europe and emerging Asia. In doing this, we identified emerging Europe and the euro area as well as emerging Asia and the United States as two different convergence clubs. This allowed us to introduce indicators of financial integration within the convergence clubs as additional explanatory variables.

Our analysis confirms that financial market development and financial integration are important factors in determining current account balances. More developed financial markets as well as a higher degree of financial integration are in general associated with higher current account deficits/lower current account surpluses.

However, several standard indicators of financial development and financial integration fail to account for the divergent patterns of the current account in emerging Europe and emerging Asia. Instead we find that the degree and institutional pattern of financial integration within the convergence clubs-together with the level of foreign exchange reserves - contribute significantly to the model's predictions of strikingly different current account patterns in emerging Europe and Asia.

These differences in financial integration point to the peculiar environment of "deep integration" between core and periphery characterising developments in the European convergence club, allowing emerging Europe to enter a growth path driven by domestic demand, in particular by investment, financed to a substantial part by foreign savings. Thus, emerging Europe has shown substantial current account deficits as predicted by standard theory. Of course, rapid financial deepening and the associated current account deficits have important macroeconomic and financial stability implications. They have been extensively reviewed in the literature (e.g., Eichengreen and Choudhry 2005) as well as by international financial institutions and central banks (ECB (European Central Bank) 2006). Thus, while the example of emerging Europe illustrates the impact of financial integration for current account developments in a process of real convergence, it does not imply that this process does not involve risks.

In emerging Asia, financial globalisation has not evolved under conditions of "deep integration". Countries entered a growth path based on export-led growth and rising current account surpluses. This raises the question whether the example of emerging Europe indicates that a transfer of credibility, quality and institutions from the core might be a precondition for emerging markets pursuing consumption-smoothing activities in a globalised financial system. We leave this question for future research.

Acknowledgments The views expressed in the paper are those of the authors and do not necessarily represent those of the Deutsche Bundesbank or the ECB (at the time of writing this paper, Adalbert Winkler was Deputy Head of Division in the ECB's Directorate General International and European Relations). Excellent research assistance by Silvia Magnoni, Livia Chitu and Michael Grill is gratefully acknowledged. The authors would also like to thank Neeltje van Hooren (World Bank) for data support. 


\section{Data Appendix}

We provide below a list of mnemonics, sources and descriptions for all the variables included in the empirical investigation. Additionally, we supply a list of all countries belonging to the Asian and European sample. In general, data were available from 1994 to 2006, except for CHINN_ITO (1994-2005), DEPENDENCY (1994-2004), INTRA INTEGRATION (1994-2005) and OVERALL INTEGRATION (1994-2004).

\begin{tabular}{|c|c|c|}
\hline Mnemonic & Source & Variable description \\
\hline CAGDP & WEO & Current account to GDP ratio \\
\hline CAPITAL & IFS & Gross capital flows (as \% of GDP) \\
\hline CHINN_ITO & CI & Capital account openness index \\
\hline CREDIT & FSD & Private credit by deposit money banks to GDP ratio \\
\hline CRISIS & CK & Systemic banking crisis index \\
\hline DEPENDENCY & IFS & Dependency ratio (dependents to working-age population) \\
\hline EXCHANGE & BIS & Logarithm of the real effective exchange rate \\
\hline $\begin{array}{l}\text { EXTERN } \\
\text { POSITION }\end{array}$ & IFS & Foreign assets minus foreign liabilities to GDP ratio \\
\hline FDIGDP & IFS & FDI as $\%$ of GDP \\
\hline $\begin{array}{l}\text { FOREIGN } \\
\text { BANKING }\end{array}$ & WB & $\begin{array}{l}\text { Foreign-owned banking assets (in } \% \text { of the total banking sector assets in } \\
\text { the periphery country) }\end{array}$ \\
\hline $\begin{array}{l}\text { GOVERNMENT } \\
\text { BALANCE }\end{array}$ & WEO & General government balance to GDP ratio \\
\hline INCOME & WEO & $\begin{array}{l}\text { Country's GDP per capita (PPP terms) to euro area average/US GDP per } \\
\text { capita (PPP terms) }\end{array}$ \\
\hline $\begin{array}{l}\text { INTEREST } \\
\text { SPREAD }\end{array}$ & IFS & Lending rate minus deposit rate \\
\hline $\begin{array}{l}\text { INTRA } \\
\text { INTEGRATION }\end{array}$ & BIS & $\begin{array}{l}\text { Consolidated foreign claims of euro area/US banks on the respective } \\
\text { emerging country as a percentage of GDP of the recipient country }\end{array}$ \\
\hline M2GDP & IFS & M2 to GDP ratio \\
\hline NPL & GFSR & Non-performing loans to total loans \\
\hline $\begin{array}{l}\text { OVERALL } \\
\text { INTEGRATION }\end{array}$ & IFS & Foreign assets plus liabilities to GDP ratio \\
\hline RESERVES & WEO & Stock of foreign exchange reserves at year-end to GDP ratio \\
\hline RIR & WDI & Real interest rates in \% \\
\hline TOT & WEO & Terms of trade, goods and services \\
\hline TRADE & WEO & Trade openness (world exports/imports in \% of GDP) \\
\hline STOCK MARKET & WEO & Stock market turnover (shares traded/GDP) \\
\hline GDP GROWTH & WEO & Real GDP growth rate to euro area average/US \\
\hline
\end{tabular}

BIS Bank for International Settlements, CI Chinn and Ito (2007); CK Caprio and Klingebiel (2003); FSD World Bank Financial Structure Data Set; GFSR IMF Global Financial Stability Report; IFS IMF International Financial Statistics; WB World Bank (Claessens et al. (2007), "Foreign Bank Presence in Developing Countries 1995-2006: Data and Trends"); WDI World Bank World Development Indicator; WEO IMF World Economic Outlook 
Emerging Asian Countries: China (CHN), Hong Kong (HKG), India (IND), Indonesia (IDN), Korea (KOR), Malaysia (MYS), the Philippines (PHL), Singapore (SGP), Taiwan (TWN), Thailand (THA), Vietnam (VNM).

Emerging European Countries: Albania (ALB), Bosnia and Herzegovina (BIH), Bulgaria (BGR), Croatia (HRV), the Czech Republic (CZE), Estonia (EST), Hungary (HUN), Latvia (LVA), Lithuania (LTU), Macedonia (MKD), Poland (POL), Romania (ROM), Serbia (CS), the Slovak Republic (SVK), Slovenia (SVN), Turkey (TUR).

\section{References}

Abiad, A., Leigh, D., \& Mody, A. (2007). International finance and income convergence: Europe is different. (IMF Working Paper 64). Washington D.C.: International Monetary Fund.

Abramovitz, M. (1986). Catching up, forging ahead, and falling behind. The Journal of Economic History, 46(2), 385-406.

Aizenman, J. (2007). Large hoarding of international reserves and the emerging global economic architecture. (NBER Working Paper 13277). Cambridge MA: National Bureau of Economic Research.

Aizenman, J., \& Lee, J. (2005). International reserves: Precautionary versus mercantilist views, theory and evidence. (NBER Working Paper No. 11366). Cambridge MA: National Bureau of Economic Research.

Anderson, T. W., \& Hsiao, C. (1981). Estimation of dynamic models with error components. Journal of the American Statistical Association, 76, 598-606.

Baumol, W. (1986). Productivity growth, convergence, and welfare: What the long-run data show. American Economic Review, 76(5), 1072-1085.

Blanchard, O., \& Giavazzi, F. (2002). Current account deficits in the euro area: The end of the FeldsteinHorioka puzzle? Brookings Papers on Economic Activity, 2, 147-210.

Bosworth, B. P., \& Collins, S. M. (1999). Capital flows to developing economies: Implications for saving and investment. Brookings Papers on Economic Activity, 1, 143-169.

Breitung, J. (2000). The local power of some unit root tests for panel data. In B. Baltagi (Ed.), Nonstationary panels, panel cointegration, and dynamic panels. (Advances in econometrics 15). Amsterdam: JAI.

Bussière, M., Fratzscher, M., \& Mueller, G.J. (2004). Current account dynamics in OECD and EU acceding countries - an intertemporal approach. (ECB Working Paper Series 311). Frankfurt a.M: European Central Bank.

Caballero, R.J. (2006). On the macroeconomics of asset shortages. (NBER Working Paper 12753). Cambridge MA: National Bureau of Economic Research.

Caprio, G., \& Klingebiel, D. (2003). Episodes of systemic and borderline financial crises. World bank research dataset. Washington D.C.: World Bank.

Chinn, M.D., \& Ito, H. (2005). Current account balances, financial development and institutions: Assaying the world 'Saving Glut'. (NBER Working Paper 11761). Cambridge MA: National Bureau of Economic Research.

Chinn, M.D., \& Ito, H. (2007). East Asia and global imbalances: Saving, investment, and financial development. (NBER Working Paper 13364). Cambridge MA: National Bureau of Economic Research.

Chinn, M. D., \& Prasad, E. S. (2000). Medium-term determinants of current accounts in industrial and developing countries: An empirical exploration. Journal of International Economics, 59(1), 47-76.

Claessens, S., Van Horen, N., Gurcanlar, T. \& Mercado, J. (2007). Foreign bank presence in developing countries 1995-2006: Data and trends. Paper presented at the expert meeting on trade and development implications of financial services, Geneva 20-21 September 2007.

Debelle, G., \& Faruqee, H. (1996). What determines the current account? A cross-sectional and panel approach. (IMF Working Paper 58). Washington D.C.: International Monetary Fund. 
Dooley, M.P., Folkerts-Landau, D., \& Garber, P.M. (2003). An essay on the revived Bretton woods system. (NBER Working Paper 9971). Cambridge MA: National Bureau of Economic Research.

Dooley, M.P., Folkerts-Landau, D., \& Garber, P.M. (2007). The two crises of international economics. (NBER Working Paper 13197). Cambridge MA: National Bureau of Economic Research.

ECB (European Central Bank) (2006). Financial stability review. Frankfurt a.M.: ECB.

Edwards, S. (1995). Why are saving rates so different across countries. (NBER Working Paper 5097). Cambridge MA: National Bureau of Economic Research.

Eichengreen, B. (2004). Global imbalances and the lessons of Bretton woods. (NBER Working Paper 10497). Cambridge MA: National Bureau of Economic Research.

Eichengreen, B. (2006). The blind men and the elephant. Issues in economic policy 1. Washington D.C.: Brookings Institution.

Eichengreen, B., \& Choudhry, O. (2005). Managing Capital Flows: Eastern Europe in an Asian Mirror. Berkeley: University of California. unpublished paper.

Felipe, J., \& Lim, J. A. (2005). Export or domestic demand-led growth in developing Asia? Asian Development Review, 22(2), 35-75.

Fry, M., Claessens, S., Burridge, P., \& Blanchet, M.-C. (1995). Foreign direct investment, other capital flows, and current account deficits-what causes what? (Policy Research Paper 1527). Washington D.C.: World Bank.

Greenspan, A. (2003). Remarks at the 21 st annual monetary conference. Washington D.C.: Cosponsored by the Cato Institute and The Economist. November 20, 2003. http://www.federalreserve.gov/boarddocs/ Speeches/2003/20031120/default.htm.

Gruber, J.W., \& Kamin, S.B. (2005). Explaining the global pattern of current account imbalances. (International Finance Discussion Papers 846). Washington D.C.: Board of Governors of the Federal Reserve System.

Hermann, S., \& Jochem, A. (2005). Determinants of current account developments in the Central and East European EU member states-consequences for the enlargement of the euro area. (Discussion Paper Series 32). Frankfurt a.M: Deutsche Bundesbank.

Im, K. S., Pesaran, M. H., \& Shin, Y. (2003). Testing for unit roots in heterogeneous panels. Journal of Econometrics, 115(1), 53-74.

IMF (International Monetary Fund) (2006a). Annual report on exchange arrangements and exchange restrictions. Washington D.C.: IMF.

IMF (International Monetary Fund) (2006b). Private consumption in emerging Asia. Asia and Pacific regional economic outlook, September 2006. Washington D.C.: IMF.

Ju, J., \& Wei, S.-J. (2006). A solution to two paradoxes of international capital flows. (NBER Working Paper 12668). Cambridge MA: National Bureau of Economic Research.

Ju, J., \& Wei, S.-J. (2007). Domestic institutions and the bypass effect of international capital flows. (NBER Working Paper 13148). Cambridge MA: National Bureau of Economic Research.

Lane, P.R., \& Milesi-Ferretti, G.M. (2006). The external wealth of nations mark II: Revised and extended estimates of foreign assets and liabilities, 1970-2004. (IMF Working Paper 69). Washington D.C.: International Monetary Fund.

Levin, A., Lin, C. F., \& Chu, C. (2002). Unit root tests in panel data: Asymptotic and finite-sample properties. Journal of Econometrics, 108(1), 1-24.

Lucas, R. (1990). Why doesn't capital flow from rich to poor countries? American Economic Review, 80(2), 93-96.

Maddala, G. S., \& Wu, S. (1999). A comparative study of unit root tests with panel data and a new simple test. Oxford Bulletin of Economics and Statistics, 61(4), 631-652.

Mendoza, E.G., Quadrini, V., \& Rios-Rull, J.-V. (2006). Financial integration, financial deepness and global imbalances. Paper presented at the 7th Jacques Polak annual research conference. International Monetary Fund, November 9-10: Washington D.C..

Mody, A., \& Murshid, A. P. (2002). Growing up with capital flows. Journal of International Economics, 65(1), 249-266.

Obstfeld, M., \& Rogoff, K. (1996). The intertemporal approach to the current account. (NBER Working Paper 4893). Cambridge MA: National Bureau of Economic Research.

Prasad, E., Rajan, R., \& Subramanian, A. (2007). The paradox of capital. (Finance and development 44 (1)). Washington D.C.: International Monetary Fund.

Pritchett, L. (1997). Divergence, big time. Journal of Economic Perspectives, 11(3), 3-17.

Rodrik, D. (2007). How to save globalization from its cheerleaders. Mimeo: Harvard University. 